\title{
Rottenstone as a basis for obtaining geopolymer material
}

\author{
V.V. Sobchenko (ORCID 0000-0002-8575-7584), V.A. Zhaivoronok (ORCID 0000-0002-9669-2843), \\ H.O. Sobchenko (ORCID 0000-0002 2411-9562)
}

The Gas Institute of the NAS of Ukraine, str. Degtyarivska, 39, Kyiv, 03113, Ukraine

Tel.: +380962972878

E-mail:via_sobchenko@ukr.net

Article info: received 02.09.2020, revised 25.09.2020, accepted 29.09.2020

Sobchenko, V.V., Zhaivoronok, V.A., Sobchenko, H.O. (2020) Rottenstone as a basis for obtaining geopolymer material 3(48), doi: $10.26909 /$ csl.3.2020.3

The possibility of obtaining perspective geopolymer materials for use in the building industry was shown. Geopolymer materials are used with such advantages as high strength, density, water resistance, heat and heat resistance, environmental friendliness, durability, and high corrosion resistance. The raw material is rottenstone, a rock with a high silica content, which is widespread in Ukraine. Rottenstone is characterized by a ratio of $\mathrm{SiO}_{2}: \mathrm{Al}_{2} \mathrm{O}_{3}$ equal to 16 ...20, which provides a high strength of the final material. It was indicated that physico-chemical processes that take place during polymerization are similar to those that take place in thin pellicles of the released $\mathrm{SiO}_{2}$ gel, cements the particles, and thus promotes hardening. As a result of the treatment of raw materials with alkali solution at temperatures of $80-120^{\circ} \mathrm{C}$, a monolithic solid material of olive color with a density of $1200-1700 \mathrm{~kg} / \mathrm{m}^{3}$, humidity of $30-45 \%$ was formed. Precipitations were observed on the surface of the material due to the presence of non-chemically bound sodium and potassium cations in the pores of the geopolymer. When dried, they diffuse to the surface of the geopolymer and are subjected to atmospheric carbonization. It was indicated that in order to obtain a high-strength geopolymer material, it is necessary to carry out final heat treatment at temperatures close to $100{ }^{\circ} \mathrm{C}$. The behavior of geopolymer samples aged over time at room temperature during their heating was investigated. The samples of the material are melted due to the presence of $\mathrm{Na}_{2} \mathrm{O} \cdot \mathrm{SiO}_{2} \cdot 8 \mathrm{H}_{2} \mathrm{O}$ and $\mathrm{Na}_{2} \mathrm{O} \cdot \mathrm{SiO}_{2} \cdot 5 \mathrm{H}_{2} \mathrm{O}$ crystal hydrates, which melt at relatively low temperatures at $48{ }^{\circ} \mathrm{C}$ and $72{ }^{\circ} \mathrm{C}$, respectively. The formation of building geopolymer materials should take into account this melting by placing it in molds was concluded. Indicators of moisture loss at a temperature of about $100{ }^{\circ} \mathrm{C}$ depending on the heat treatment time were obtained.

Key words: rottenstone, geopolymers, heat treatment.

\section{Трепел як основа одержання геополімерного матеріалу}

\author{
В.В. Собченко, В.А. Жайворонок, Г.О. Собченко \\ Інститут газу НАН Украӥни, Київ, Україна
}

Показано можливість одержання перспективних геополімерних матеріалів для використання у будівельній індустрії. Геополімерні матеріали знаходять своє використання маючи такі переваги як висока міцність, густина, водостійкість, тепло та термостійкість, екологічність, довговічність та висока корозійна стійкість. Сировиною $\epsilon$ розповсюджений на території України трепел, порода з високим вмістом кремнезему. Трепел характеризується відношенням $\mathrm{SiO}_{2}: \mathrm{Al}_{2} \mathrm{O}_{3}$ рівним 16...20, що забезпечує високий показник міцності кінцевого матеріалу. Вказано, що фізико-хімічні процеси, які протікають при полімеризації аналогічні тим, що проходять в тонких плівках. Гель $\mathrm{SiO}_{2}$, що виділився, цементує частинки і таким чином сприяє твердінню. У результаті обробки сировини розчином лугу при температурах $80-120{ }^{\circ} \mathrm{C}$ утворюється монолітний твердий матеріал маслинового

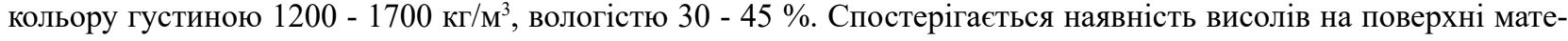
ріалу, що пояснюється наявністю в порах геополімера води та катіонів натрію і калію, хімічно з ним не зв'язаних. При сушінні вони дифундують на поверхню геополімеру та піддаються атмосферній карбонізації. Вказано, що для одержання геополімерного матеріалу високої міцності необхідно проводити кінцеву термообробку при температурах близьких до $100^{\circ} \mathrm{C}$. Досліджено поведінку витриманих у часі при кімнатній температурі зразків 
геополімеру при їх нагріві. Проходить оплавлення зразків матеріалу, що обумовлено наявністю кристалогідратів $\mathrm{Na}_{2} \mathrm{O} \cdot \mathrm{SiO}_{2} \cdot 8 \mathrm{H}_{2} \mathrm{O}$ та $\mathrm{Na}_{2} \mathrm{O} \cdot \mathrm{SiO}_{2} \cdot 5 \mathrm{H}_{2} \mathrm{O}$, які плавляться при порівняно низьких температурах, при $48{ }^{\circ} \mathrm{C}$ i $72{ }^{\circ} \mathrm{C}$ відповідно. Зроблено висновок, що при формуванні будівельних геополімерних матеріалів слід враховувати це оплавлення шляхом його розміщення у формах. Одержано показники втрати вологи при температурі близько $100{ }^{\circ} \mathrm{C}$ в залежності від часу термообробки.

\section{Вступ}

Будівництво є однією 3 найбільш матеріалоємних галузей. Для виробництва будівельних матеріалів в світі щорічно видобуваються мільярди тон мінеральної сировини 3 необхідністю використання портландцементу в якості в’яжучого матеріалу. В Україні $є$ актуальною необхідність розробки технологій виробництва вітчизняних високоякісних теплоізоляційних матеріалів з місцевої сировини для використання у будівництві.

Одним 3 прогресивних напрямків сучасного будівельного матеріалознавства $\epsilon$ розробка та використання геополімерних в'яжучих при виробництві високоякісних будівельних матеріалів [1, 2]. Геополімерні в'яжучі одержують в результаті лужної обробки сировини природного та техногенного походження (каолінів, гірських порід, шлаків, зол TEC тощо).

Геополімерні матеріали мають такі переваги, як висока міцність, густина, водостійкість, тепло та термостійкість, екологічність, довговічність та висока корозійна стійкість. [2, 3] Вони розглядаються як перспективна альтернатива портландцементу. Відповідно класифікації геополімерні матеріали розділяють: геополімери на основі гірських порід, на основі золи-виносу, на основі шлаку, на основі феросилітів, на основі золи-виносу та шлаку. Davidovits J. підкреслює, що до геополімерних матеріалів можливо відносити лише ті алюмосилікати, твердіння яких активується лугами, коли відбувається синтез полімерної структури з мономірних силікатних та алюмінатних груп. [1]

Процеси утворення геополімерних матеріалів недостатньо досліджені [2]. В Україні займались дослідженнями для створення умов розвитку геополімерних матеріалів В.Д. Глуховський, П.В. Кривенко та інші $[4,5]$. При дослідженні геополімерів ставляться задачі оцінки впливу складу сировинних матеріалів і технологічних параметрів виробництва на їх фізико-хімічні та фізико-механічні властивості.

Інститутом газу НАН України проводяться дослідження процесів одержання теплоізоляційних матеріалів, в тому числі із лужноактивованої кремнеземнистої сировини з розробкою технологій їх виробництва $[6,7]$.

Мета роботи. Провести технологічні дослідження можливості одержання геополімерів на основі трепелу.

\section{Матеріали та методи дослідження}

Серед сировинних матеріалів, які найбільш підходять для виробництва геополімерних в'яжучих $\epsilon$ водорозчинні силікати лужних металів. Відомо, що в природних умовах в результаті низькотемпературних гідротермальних реакцій утворюються атмосферостійкі гідроалюмосилікати - цеоліти, слюди і т.д.

Наявність природної сировини; невисока іiі вартість; можливість реалізації екологічно чистої і безвідходної технології отримання будівельного матеріалу; досвід досліджень матеріалів, які мають в складі кремнезем; можливість утворення

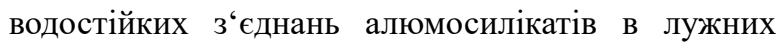
розчинах; твердження, що суміш розчину силікату натрію і доля колоїдного кремнезему в співвідношенні $\mathrm{SiO}_{2}: \mathrm{Na}_{2} \mathrm{O}=10: 1$ при $150{ }^{\circ} \mathrm{C}$ перетворюється в прозоре водостійке покриття, одержання геополімерів 3 найбільш високими показниками міцності забезпечується відношенням в сировині $\mathrm{SiO}_{2}: \mathrm{Al}_{2} \mathrm{O}_{3}$ рівним 16...20 [2]. Ці факти стали основою для синтезу природного аналогу шляхом гідратації лужних і лужноземельних систем при частковому заміщенні лугів гідроксилами.

Для досліджень використано сировину трепел (на території України в наявності більше 3-х десятків розвіданих родовищ) - порода з вмістом до $75 \%$ аморфного кремнезему (опала $-\mathrm{SiO}_{2} \mathrm{mH}_{2} \mathrm{O}$ ) у виді частинок сферичної форми розміром 8 - 12 мкм, іноді 15 - 20 мкм, зцементованих тонким шаром (1 - 2 мкм) глинистої речовини, переважно, каолініту. Хімічний склад трепелу характеризується: $\mathrm{SiO}_{2}-79 \ldots 85 \%, \mathrm{Al}_{2} \mathrm{O}_{3}-5 \ldots 6,7 \%, \mathrm{Fe}_{2} \mathrm{O}_{3}-2,3 \ldots 3,7 \%$, $\mathrm{CaO}+\mathrm{MgO}-1,5 \ldots 4,5 \%$. У трепелі присутні уламки кварцу розміром до 200 мкм у кількості близько $15 \%$ і незначна кількість магнетиту.

Найбільш ефективно процес полімеризації протікає при РН-8, тому одержання геополімеру здійснювалося інтенсивним перемішуванням трепелу з водним розчином каустичної соди 42 - 48 \% концентрації при температурі $80-120^{\circ} \mathrm{C}$ протягом 15 - 30 хв. [8]. Далі проходить процес охолодження. У результаті утворюється матеріал у вигляді монолітної однорідної твердої маси маслинового кольору густиною $1200-1700 \mathrm{\kappa г} / \mathrm{M}^{3}$, вологістю $30-45 \%$, що містить у собі кристалогідрати типу $\mathrm{Na}_{2} \mathrm{O} \cdot \mathrm{mSiO}_{2} \cdot \mathrm{nH}_{2} \mathrm{O}$. В ньому присутня також певна кількість непрореагованих частинок трепелу роз- 
міром 0,5 - 2 мм. Фото одержаного матеріалу представлено на рис. 1 .

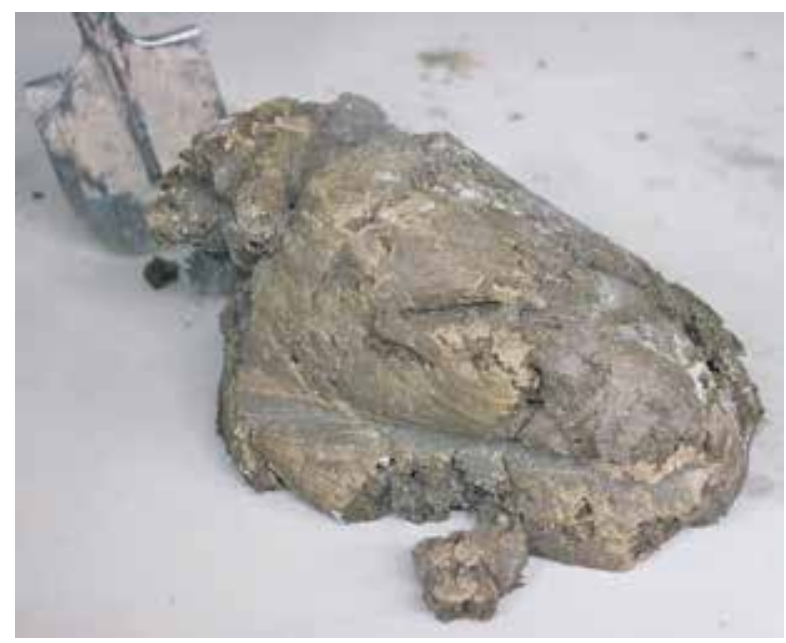

Рис. 1. Фото одержаного гідросилікатного матеріалу

Дослідженнями [6] визначено, що в складі одержаного матеріалу 80 \% води знаходиться в сорбованому стані, $19 \%$ - хімічно зв'язана вода (кристалогідратна), 1 \% - механічно включена. Матеріал являє собою ламку масу, що легко подрібнюється та плавиться навіть при адсорбції вологи повітря. Проходить поступове видалення рідкої фази - зневоднювання.

Повне видалення води зазвичай проходить після їх нагріву до температур більше $900-1000^{\circ} \mathrm{C}$ чи довгої витримки [8]. Паралельно 3 дегідратацією проходить карбонізація, хоча і швидкість цього процесу досить мала і залежить від силікатного модуля. Швидкість карбонізації зростає з зменшенням силікатного модуля. Фізико-хімічні процеси, які протікають при полімеризації аналогічні тим, що проходять в тонких плівках: гель $\mathrm{SiO}_{2}$, що виділився, цементує частинки і таким чином сприяє твердінню. Зразки одержаного матеріалу досліджувались після витримки при кімнатній температурі. При візуальному огляді є присутність непрореагованих частинок трепелу розміром не більше 0,5 мм та наявність висолів на поверхні матеріалу. Поясненням $є$ те, що в порах геополімера присутня вода та катіони натрію і калію, хімічно з ним не зв'язані. При сушінні вони дифундують на поверхню геополімеру та піддаються атмосферній карбонізації.

\section{Результати та їх обговорення}

Концентровані розчини неорганічних полімерів нестійкі. Вони утворюються з виділенням гелів або перетворюватися в коагуляти. Факторами, які обумовлюють процеси полімеризації є температура, $\mathrm{pH}$, хімічна реакція тощо. Плавлення лужних роз- чинів - це утворення полімерів 3 силікатних іонів чи молекул $\mathrm{SiO}_{2}$ які конденсуються до формування частинок аморфного кремнезему. В'яжучі властивості матеріалу визначаються полісилікатіонами, концентрація яких росте з збільшенням відношення $\mathrm{SiO}_{2}: \mathrm{Na}_{2} \mathrm{O}$. Процес конденсації закінчується затвердінням неорганічного полімеру.

Розрізняють два етапи розм'якшення: умовне і фактичне плавлення. Умовне плавлення обумовлене адсорбцією вологи повітря. Фактичне плавлення зв'язане з нагрівом геополімеру. В чистому вигляді матеріал при контакті з водою в неї не переходить, але проходить послаблення зв'язків між колоїдними частинками при нагріванні. Дійсно, при нагріванні до $100^{\circ} \mathrm{C}$ матеріал починає розм'якати, але не розтікається під власною вагою. В [2] показано, що міцність на стиск висушених зразків гідросилікату (при $105^{\circ} \mathrm{C}$ на протязі 24 годин) вище, ніж міцність зразків без сушіння. Це пов'язано з тим, що сушіння при вказаній температурі прискорює швидкість дегідратації та геополімеризацію переходом гелю гідросилікату в кристалічну форму. До основних факторів, які впливають на міцність зразків геополімеру відносять час та температуру твердіння.

Для контролю розм“якшення зразка при його нагріві було виготовлено прилад. Схема приладу представлена на рис. 2. Для фіксації величини розм'якшення зразків і процесу спучування вага штока індикатора була зменшена до 1...2 г. Нагрів зразка геополімеру відбувався 3 швидкістю 7 - $10{ }^{\circ} \mathrm{C} /$ хв. При нагріві циліндричного зразка діаметром 5 мм і висотою близько 5 мм, вирізаного 3 глиби порожньотілим свердлом, починаючи з 50 - $60{ }^{\circ} \mathrm{C}$ проходить інтенсивний процес розм'якшення. 3 рис. 3 видно, що розм'якшення зразків не припиняється і при температурі більше $100{ }^{\circ} \mathrm{C}$.

Це свідчить, що процес розм'якшення зразка обумовлений наявністю в геополімері кристалогідратів, які плавляться при порівняно низьких температурах. Наприклад, $\mathrm{Na}_{2} \mathrm{O} \cdot \mathrm{SiO}_{2} \cdot 8 \mathrm{H}_{2} \mathrm{O}$ плавиться при $48^{\circ} \mathrm{C}$, a $\mathrm{Na}_{2} \mathrm{O} \cdot \mathrm{SiO}_{2} \cdot 5 \mathrm{H}_{2} \mathrm{O}-$ при $72^{\circ} \mathrm{C}$ [8].

Під тиском ваги штоку індикатора оплавлення матеріалу зразка (зменшення по висоті) закінчується при температурі $\approx 135^{\circ} \mathrm{C}$. Потім фіксується різкий підйом штоку - спучування деформованого (бочкоподібного) зразка і утворення сфери практично правильної форми. Після завершення процесу спучування при 150 - $160{ }^{\circ} \mathrm{C}$ проходить повторне опускання штоку, тобто зразок стає в'язким до температур близько $200{ }^{\circ} \mathrm{C}$.

В таблиці 1. приведені результати втрати вологи зразка при 100 - $105^{\circ} \mathrm{C}$ в залежності від часу термообробки в інтервалі 15 - 300 хв. Після 15 хв. термообробки в неоднорідній ізотропній фазі фіксується наявність дрібних кристалів, близьких до криста- 


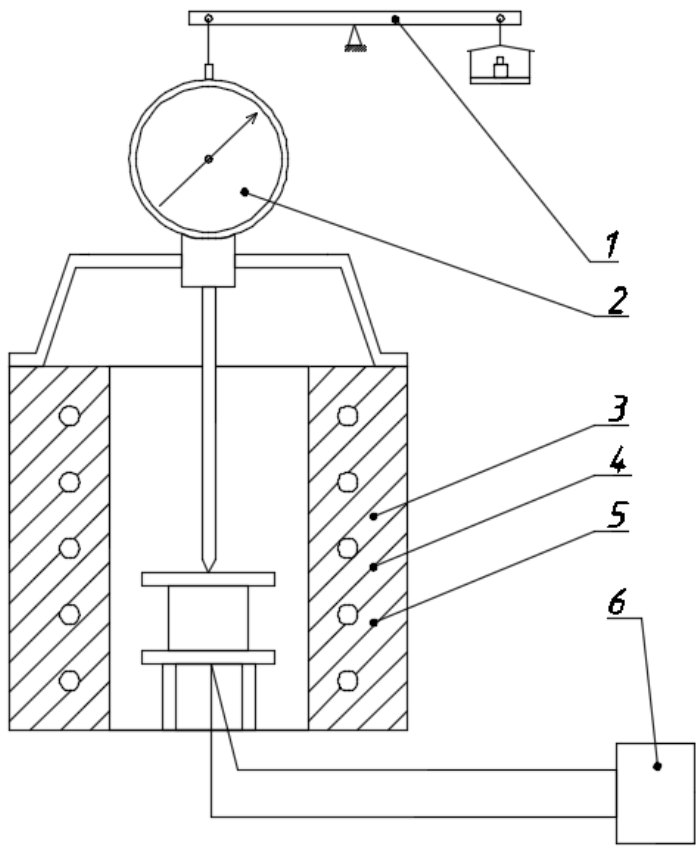

Рис. 2. Схема приладу для контролю розм'якшення зразка при його нагріві: 1 - ричаг-коромисло; 2 - індикатор; 3 - піч (електронагрівник); 4 - дослідний зразок; 5 - термоелектричний перетворювач; 6 - потенціометр

логідратів $\mathrm{Na}_{2} \mathrm{O} \cdot \mathrm{SiO}_{2} \cdot 8 \mathrm{H}_{2} \mathrm{O}$, а інший вид ідентифікується як $\mathrm{NaOH} \cdot 2 \mathrm{H}_{2} \mathrm{O}$. Збільшення часу витримки зразків призводить до гомогенізації матеріалу. При витримці близько 300 хв візуально зникають скупчення відносно крупних кристалів $\mathrm{NaOH} \cdot 2 \mathrm{H}_{2} \mathrm{O}$. Вважається, що проходить перекристалізація.

Нагрівання геополімеру при більш високих температурах супроводжується подальшою перекристалізацією гідросилікатів натрію з одночасною втратою води ізотропною фазою, що покращує водостійкість кінцевого матеріалу. Повне видалення води фіксується при температурі порядку $550{ }^{\circ} \mathrm{C}$, а при температурі $600{ }^{\circ} \mathrm{C}$ - матеріал перетворюється в пористе скло.

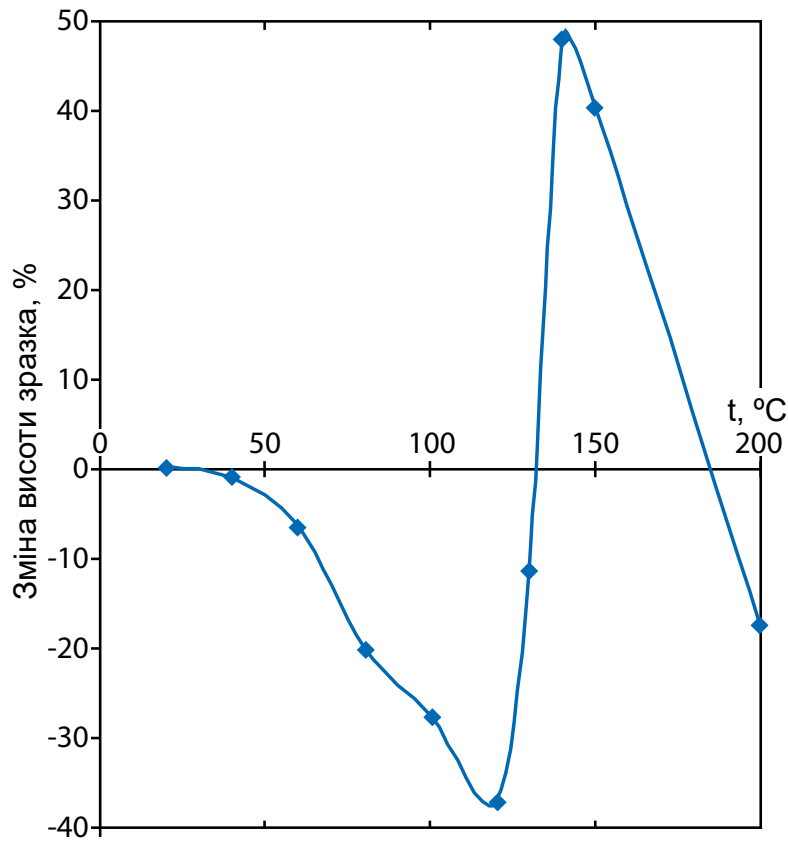

Рис. 3. Крива розм'якшення і спучування зразка геополімеру в залежності від температури нагрівання

\section{Висновки}

Показана можливість одержання геополімерів на основі трепелу. При синтезі атоми кремнію та алюмінію створюють міцні розгалужені мережі $\mathrm{Si-O}-\mathrm{Al}-\mathrm{O}$, завдяки яким матеріал має високі фізико-механічні властивості. Досліджено зразки витриманого в часі матеріалу при їх нагріві та одержано показники втрати вологи. Показано, що для одержання геополімерного матеріалу високої міцності необхідно проводити кінцеве термооброблення при температурах близьких до $100{ }^{\circ} \mathrm{C}$. Досліджено процес плавлення матеріалу та втрати вологи при вказаній температурі.

Таблиця 1.

Втрата маси матеріалу від часу термообробки при температурі близько $100{ }^{\circ} \mathrm{C}$

\begin{tabular}{|c|c|c|c|c|c|}
\hline Час, хв. & 15 & 30 & 120 & 180 & 300 \\
\hline & 14 & 15,55 & 20,93 & 22,48 & 23,34 \\
Втрата маси, \% & 15,69 & 19,35 & 23,7 & 25,1 & 24,17 \\
& 12,2 & 17,43 & 21,86 & 23,83 & 24,77 \\
\hline
\end{tabular}




\section{References}

1. Davidovits, J. Geopolymer chemistry and applications // 3rd edition. - France, Saint-Quentin: Institute Geopolymer. - 2011. -614 p.

2. Н.А. Ерочкина, М.О. Коровкин. Геополимерные строительные материалы на основе промышленных отходов. - Пенза: ПГУАС. $-2014 .-128$ с.

3. Корнеев, В.И. Перспективы развития общестроительных вяжущих веществ. Геополимеры и их отличительные особенности / В.И. Корнеев, А.С. Брыков // Цемент и его применение. - 2010. - № 2. - С. 51 - 55. 4. Глуховский, В.Д. Вяжущие композиционные материалы контактного твердения / В.Д. Глуховский, Р.Ф. Рунова, С.Е. Максумов. - К: Вища школа. 1991. $-243 \mathrm{c}$.
5. Кривенко, П.В. Щелочные алюмосиликатные полимеры / П.В. Кривенко, Ж.В. Скурчинская, О.А. Бродко, Г.В. Желудков // Материалы для строительных конструкций. 1CMB'94: тез. докл. III междунар. науч. конф. - Днепропетровск. - 1994. - С. 13. 6. Эйне, И.А., Хвастухин, Ю.И. Кремнезит - новый энерго- и ресурсосберегающий строительный материал // Экотехнологии и ресурсосбережение. 2000. - №5, - С. 13 - 18.

7. Костогриз, К.П. Розвиток технології термічної обробки дисперсних матеріалів / Костогриз К.П., Хвастухін Ю.І., Орлик В.М., Собченко В.В., Максимук О.Б. // Энерготехнологии и ресурсосбережение. - 2019. - № 4. - С. 47 - 59.

8. Г.В. Куколев. Химия кремния и физическая химия силикатов. - М.: Высшая школа. - 1966. - 464 с. 